\title{
EPIGEAN SPIDER DIVERSITY IN THE CLASSICAL KARST
}

\author{
Matjaž GREGORIČ*1 \& Matjaž KUNTNER ${ }^{1}$
}

\begin{abstract}
The classical Karst (Kras in Slovenian) is a limestone karst plateau of south-western Slovenia and northeastern Italy surrounded by flysch or alluvial areas. We explored surface spider species richness in the Karst by conducting a season-long quantitative inventory of the epigean fauna. By examining three localities, each with three succession-stage sites (grassland, overgrowth, forest) we tested for differences in alpha and beta diversity among different successions based on species incidence data. A total of 90 ethylene glycol pitfall traps (10 traps per each of nine sites) operated between 24. V. 2005 and 20. VII. 2006. We recorded a total of 3681 adult spiders belonging to 136 species, 82 genera and 30 families. Of these 28 species are new records for Slovenia. The observed species richness and total adult spider abundances were highest in the spring and early summer, and among succession stages they were highest in grassland (95 species; 1563 individuals), followed by overgrowth (81 species; 1047 individuals) and forest (64 species; 1071 individuals). By comparing our results with previous pitfall samplings in the Dinaric karst, we conclude that the sampling effort needed for a meaningful estimation of epigean spider diversity was barely sufficient in our study when all data were combined, but completely inadequate in previous samplings. In our study the total species richness was estimated by nonparametric statistics to lie at 181, thus $25 \%$ richer than observed. The spider fauna of Slovenia, including this contribution, currently standing at 615 species, continues to be inadequately known.
\end{abstract}

Keywords: alpha diversity, Araneae, beta diversity, Slovenia, species richness.

\section{Izvleček}

Matični Kras je apnenčasta planota jugozahodne Slovenije in severovzhodne Italije, obdana večinoma z območji fliša. Z vsesezonskim, kvantitativnim vzorčenjem smo ugotavljali vrstno pestrost površinske favne pajkov na Krasu. Na treh lokalitetah, razdeljenih v tri sukcesijske stopnje (travnik, zaraščanje, gozd), smo na podlagi pojavljanja vrst ugotavljali razlike v alfa in beta diverziteti. Med 24. V. 2005 in 20. VII. 2006 je delovalo skupno 90 etilenglikolskih pasti (10 na vsakem vzorčnem mestu), v katere se je ujelo 3681 odraslih osebkov pajkov, ki pripadajo 136 vrstam, 82 rodovom in 30 družinam. Med temi je 28 vrst prvič zabeleženih v Sloveniji. Diverzitete in abundance so bile najvišje na travnikih (95 vrst; 1563 osebkov), nato na zaraščanjih (81 vrst; 1047 osebkov) in v gozdu (64 vrst; 1071 osebkov). V primerjavi s predhodnimi vzorčenji na Dinarskem krasu je intenziteta vzorčenja $v$ naši raziskavi (vsi podatki združeni) komaj zadovoljiva za oceno vrstne pestrosti površinske favne pajkov, intenziteta $\mathrm{v}$ predhodnih vzorčenjih pa popolnoma neustrezna. $\mathrm{V}$ naši raziskavi je bilo skupno vrstno bogastvo z neparametrično statistiko ocenjeno na 181 vrst, kar je $25 \%$ več, kot smo jih zabeležili. Favna pajkov Slovenije, ki vključno s to raziskavo šteje 615 vrst, ostaja še vedno nepopolno poznana.

Ključne besede: alfa diverziteta, beta diverziteta, Slovenija.

\footnotetext{
* Corresponding author.

${ }^{1}$ Institute of Biology, Scientific Research Centre of the Slovenian Academy of Sciences and Arts, Novi trg 2, P. O. Box 306, SI-1001 Ljubljana, Slovenia. E-mail: Matjaz.Gregoric@gmail.com; Kuntner@gmail.com

Phone: +3861470 6325; Fax: +38614257797
} 


\section{INTRODUCTION}

The spider fauna of Slovenia is insufficiently known and species previously not recorded turn up in most inventories (Kuntner \& Šereg 2002). However, regional differences within Slovenia are notable, the Alpine northwest being better known, and less diverse, than the south-western region (Kuntner 1997a). The latter was the focus of this study, where we investigated the spider fauna diversity of the classical Karst ("Kras" or "matični Kras" in Slovenian), which is the geographical name for the limestone karst plateau of south-western Slovenia and north-eastern Italy, surrounded by flysch and alluvial areas (Fig. 1; Kokalj \& Oštir 2007).

Karst is a Submediterranean part of the wider Dinaric karst area, which stretches from NE It- aly through SW Slovenia into the Balkans. The spider fauna of the Slovenian Dinaric karst has received considerable faunistic attention. Species lists exist for the areas of Nanos (Polenec 1963, 1969), Divača (Polenec 1965, 1968), from the slopes of Javorniki and Slivnica (Polenec 1971), Snežnik (Polenec 1973) and from Slavnik (Polenec 1978). Some individual distribution records can also be found in the red list of endangered species from 1992 (Polenec 1992). More recent spider distribution data in the Dinaric karst are from Brkini, Slavnik, Osp, Podtabor, the surroundings of Podgrad (Kuntner 1997a) and from Vipava valley and the region around Komen (Kuntner \& Kostanjšek 2000), with further distributional records found in reviews of the Slovenian spider fauna (Kuntner 1997b, 1997c; Kuntner \& Sereg 2002). These have indicated that the

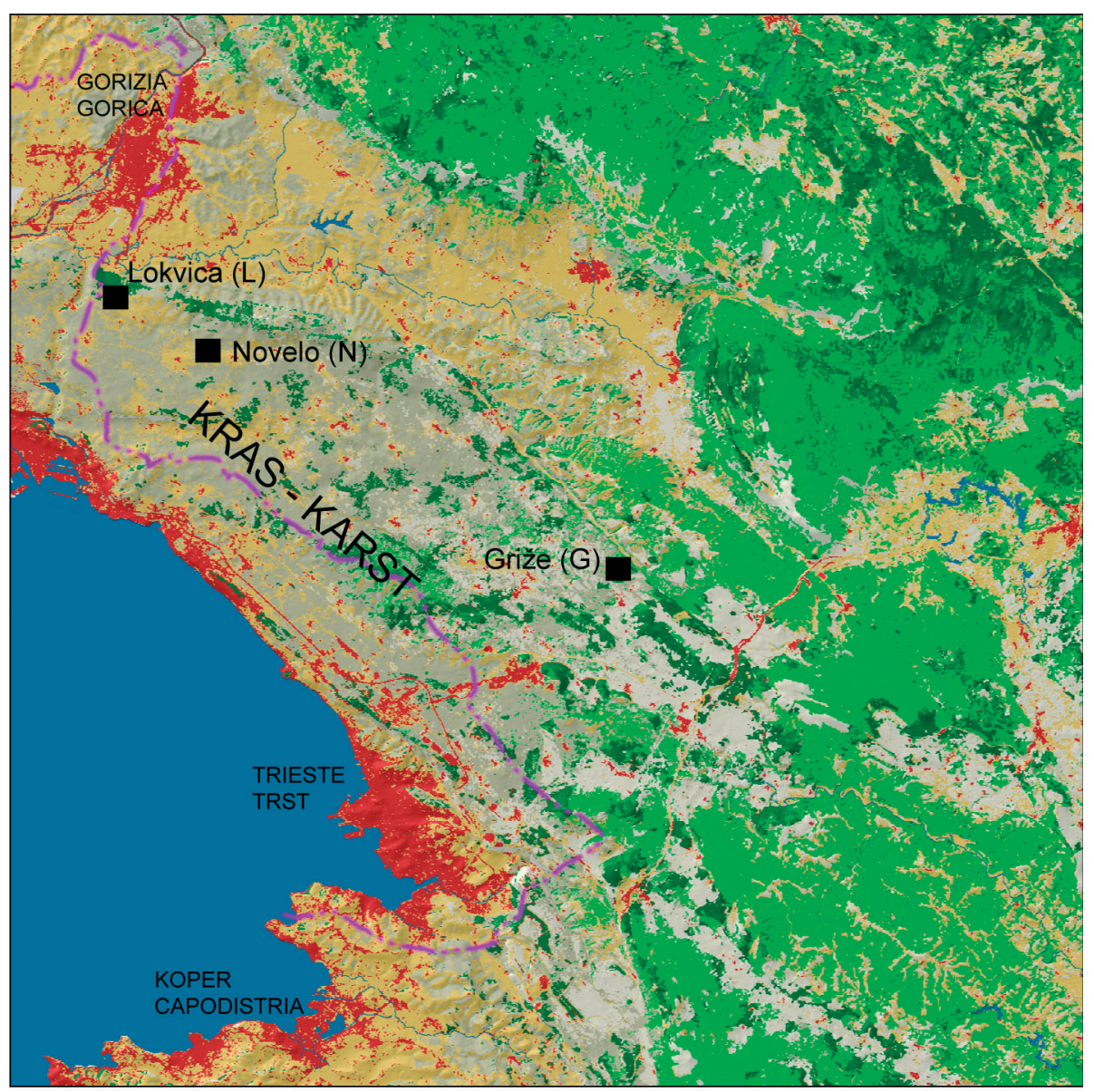

coniferous forest deciduous forest mixed forest

bushes and overgrowth
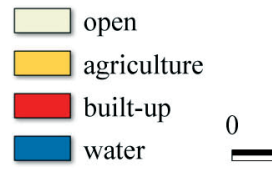

Figure 1: A map of the classical Karst (Kras) plateau in Slovenia and Italy, with sampling localities indicated. Land cover data and map modified from Kokalj and Oštir (2007).

Slika 1: Karta matičnega Krasa v Sloveniji in Italiji z označenimi vzorčnimi mesti. Podatkovni sloj in karta prirejena po Kokalj \& Oštir (2007). 
Dinaric karst may harbour a remarkably rich and endemic spider fauna. This appears to hold true not only for the subterranean spiders - the Dinaric karst has the highest density of limestone caves and is a hotspot of subterranean biotic diversity (Culver \& al. 2006; Zagmajster \& al. 2008) - but also for the surface spider fauna of the Dinaric karst, which is rich compared to other Slovenian regions (Kuntner 1997a; Kuntner \& Kostanjšek 2000).

The aim of our study was to explore the Karst epigean spider richness by a season-long inventorying of epigean spiders in the Slovenian part of the Karst. For a preliminary comparison of species richness (Coddington \& al. 1996; Scharff \& al. 2003) and other measures of diversity (Colwell \& Coddington 1994) with previous pitfall trapping inventories in the Dinaric karst (Polenec 1963, $1965,1968,1969,1978)$, we employed a quantitative sampling. We were particularly interested in establishing a minimal sampling effort needed for a meaningful estimation of epigean spider diversity. Furthermore, through structured sampling we investigated potential differences in alpha and beta diversity among three types of surface habitats typical of the Karst, i. e. the succession stages (grassland, overgrowth, forest).

\section{MATERIALS AND METHODS}

Sampling was done at three localities in the Karst (Table 1, Fig. 1). At each locality we demarcated three sites with the following succession stages: grassland, overgrowth and forest. Ten pitfall traps consisting of ethylene glycol filled plastic cups (nine centimetre diameter) with improvised roofs were randomly installed at each site. A total of 90 traps (10 traps per site, 30 traps per locality) operated between 24. V. 2005 and 20. VII. 2006. The pitfall contents were collected 12 times (7. VI. 2005, 23. VI. 2005, 20. VII. 2005, 24 . VIII. 2005, 21. IX. 2005, 27. X. 2005, 25. XI. 2005, 4. IV. 2006, 22. V. 2006, 7. VI. 2006, 23. VI. 2006 and 20. VII. 2006). In the laboratory, all juvenile spiders were discarded without counting, as is standard in quantitative spider inventories (Coddington \& al. 1996, 2009; Kuntner \& Baxter 1997; Kuntner 1999; Kuntner \& Kostanjšek 2000; Sørensen \& al. 2002; Scharff \& al. 2003; Cardoso \& al. 2008). All adults were moved to $70 \%$ ethanol and identified to species, where possible. Species abundances per pitfall trap were recorded (data available from the authors) but only total species abundances per site are reported here.

Alpha diversity $(\alpha)$ is simply the number of species of an area (site/succession stage/locality) (Whittaker 1977; Moreno \& Halffter 2001). Beta diversity $(\beta)$, a measure of species turnover between areas, was calculated as the spatial $\beta$ diversity of Moreno and Halffter (2001), also known as the complementarity index of Colwell \& Coddington (1994), both giving the percentage of species present in only one of the two compared areas: $\beta=\left(\mathrm{S}_{i}+S_{j}-2 \mathrm{~V}_{i j}\right) /\left(\mathrm{S}_{i}+\mathrm{S}_{j}-\mathrm{V}_{i j}\right) * 100$, where $\mathrm{S}_{i}$ and $S_{j}$ is the number of species on area $i$ and $j ; \mathrm{V}_{i j}$ is the number of species occurring in both areas. Beta diversity ranges between 0 and 100, corresponding to the areas containing identical and entirely different species compositions, respectively.

Table 1: List of sampling sites, each with a code, name of nearest town, succession stage, Gauss-Krüger coordinates and elevation.

Tabela 1: Seznam vzorčnih mest, vsako s svojo oznako, imenom najbližjega kraja, sukcesijsko stopnjo, GaussKrüger koordinatami in nadmorsko višino.

\begin{tabular}{lllcc} 
Code & Locality & Succession stage & Coordinates $(\mathbf{y} ; \mathbf{x})$ & Elevation $(\mathbf{m})$ \\
\hline G1 & Griže & grassland & $418645 ; 68372$ & 434 \\
G2 & Griže & overgrowth & $418752 ; 67905$ & 484 \\
G3 & Griže & forest & $418713 ; 67948$ & 484 \\
L1 & Lokvica & grassland & $390884 ; 81058$ & 188 \\
L2 & Lokvica & overgrowth & $392467 ; 81121$ & 273 \\
L3 & Lokvica & forest & $390908 ; 80648$ & 200 \\
N1 & Novelo & grassland & $396176 ; 79097$ & 325 \\
N2 & Novelo & overgrowth & $395934 ; 79663$ & 359 \\
N3 & Novelo & forest & $395939 ; 79612$ & 359 \\
\hline
\end{tabular}


We used Chao1 as an index of nonparametric species richness estimaton, which gives an estimate of the absolute number of species in an assemblage based on the number of rare species (singletons and doubletons) in a sample (Chao, 1984; Colwell \& Coddington 1994). This has been the most widely used species richness index in spider inventories (Coddington \& al. 1996, 2009; Kuntner \& Baxter 1997; Kuntner 1999; Kuntner \& Kostanjšek 2000; Sørensen \& al. 2002; Scharff $\&$ al. 2003; Cardoso \& al. 2008). A preliminary checklist of Slovenian spiders (unpublished but available from the authors) was used to determine which species were new for Slovenia.

\section{RESULTS}

Altogether 3681 adult individuals belonging to 136 species, 82 genera and 30 families were recorded at 9 sites (Table 2). Of these, 28 species are new records for the Slovenian spider fauna (asterisked in Table 2). Three species are found on the red list of endangered species of Slovenia (Uradni list Republike Slovenije 2002): Zelotes oblongus and Pseudeuophrys lanigera are classified as $\mathrm{R}$ (potentially endangered due to rarity), and Eresus cinnaberinus is classified as Q1 (potentially endangered). The two most abundant species were lycosids, Hogna radiata and Pardosa lugubris with a total of 525 and 457 individuals, respectively. Thirty-eight species were singletons and 16 were doubletons (species represented in the total sample by one and two individuals, see Colwell \& Coddington 1994; Coddington \& al. 1996, 2009). Total diversity and abundances through the season were highest in the spring and early summer (Fig. 2. a and 2. b).
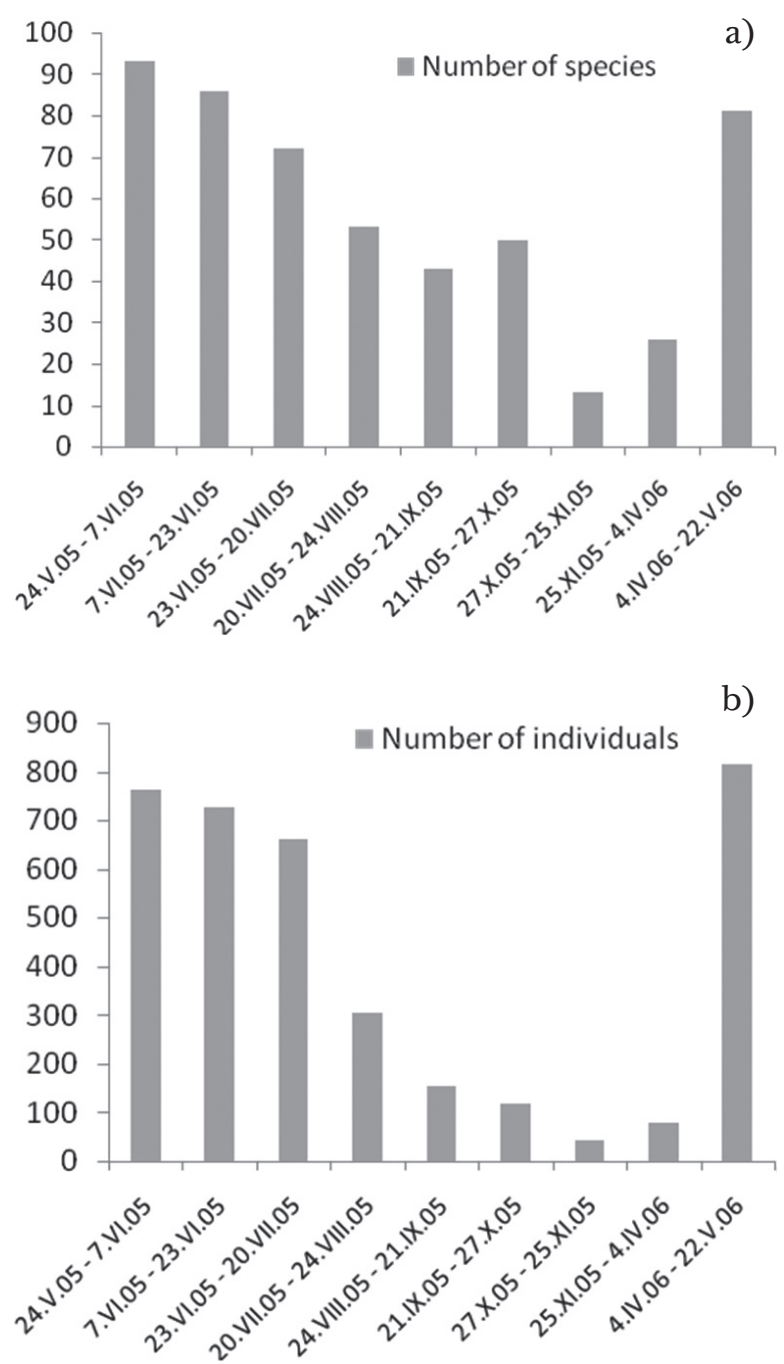

Figure 2 (a; b): The number of species (Figure 2. a) and total number of adult individuals (Figure 2. b) per sampling cycle. Slika 2 (a; b): Število vrst (Slika 2. a) in skupno število odraslih osebkov (Slika 2. b) v času vzorčenja.

Table 2: List of spider species collected in the Karst plateau in 2005 and 2006, nomenclature according to Platnick (2008), with locality codes (see Table 1) and total number of specimens per species. Species marked with an asterisk are new records for the Slovenian spider fauna.

Tabela 2: Seznam vrst pajkov, nabranih na Krasu v letih 2005 in 2006, nomenklatura sledi Platnicku (2008), ki jim sledijo oznake vzorčnih mest (glej Tabela 1) in skupno število osebkov. Vrste, označene z zvezdico, so novi podatki za Slovenijo.

G1

G1, G2, G3, L1, L2, L3, N2, N3

$\mathrm{G} 1, \mathrm{G} 2, \mathrm{G} 3$

G1, G2, G3, L3, N3 33

G1, G2, G3, N2

G1, G3

171


Family and species

\section{Amaurobiidae}

Amaurobius ferox (Walckenaer, 1830)

Eurocoelotes inermis (L. Koch, 1855)

Araneidae

Araneus diadematus Clerck, 1757

Argiope bruennichi (Scopoli, 1772)

Cercidia prominens (Westring, 1851)

Atypidae

Atypus affinis Eichwald, 1830

Clubionidae

Clubiona diversa O. P.-Cambridge, 1862 *

Clubiona terrestris Westring, 1851

Corinnidae

Phurolithus fesivus (C. L. Koch, 1835)

Dictynidae

Argenna subnigra (O. P.-Cambridge, 1861) *

Lathys nielseni (Schenkel, 1932) *

\section{Dysderidae}

Dysdera crocata C. L. Koch, 1838

Dysdera erythrina (Walckenaer, 1802)

\section{Eresidae}

Eresus cinnaberinus (Olivier, 1789)

\section{Gnaphosidae}

Aphantaulax cincta (L. Koch, 1866) *

Callilepis schuszteri (Herman, 1879)

Drassodes lapidosus (Walckenaer, 1802)

Drassodes pubescens (Thorell, 1856)

Drassyllus praeficus (L. Koch, 1866)

Drassyllus pumilus (C. L. Koch, 1839) *

Drassyllus villicus (Thorell, 1875) *

Haplodrasus dalmatensis (L. Koch, 1866)

Haplodrasus signifier (C. L. Koch, 1839)

Haplodrasus silvestris (Blackwall, 1833)

Micaria albovittata (Lucas, 1846)

Micaria formicaria (Sundevall, 1831)

Micaria fulgens (Walckenaer, 1802)

Poecilochroa variana (C. L. Koch, 1839)*

Trachyzelotes pedestris (C. L. Koch, 1837)

Zelotes apricorum (L. Koch, 1876)

Zelotes atrocaeruleus (Simon, 1878)

Zelotes erebus (Thorell, 1871)

Zelotes hermani (Chyzer, 1897)

Zelotes oblongus (C. L. Koch, 1833)

Zelotes petrensis (C. L. Koch, 1839)

Zelotes pygmaeus Miller, 1943 *

Hahniidae

Hahnia helveola Simon, 1875

Linyphiidae

Centromerus persimilis (O. P.-Cambridge, 1912) *

Centromerus sylvaticus (Blackwall, 1841)

Erigone dentipalpis (Wider, 1834)

Frontinellina frutetorum (C. L. Koch, 1834)

Gonatium rubens (Blackwall, 1833)

Linyphia triangularis (Clerck, 1757)
Site (see Table 1)

Total abundance

$\mathrm{G} 2, \mathrm{G} 3, \mathrm{~N} 3$

$\mathrm{G} 1, \mathrm{G} 2, \mathrm{G} 3, \mathrm{~L} 1, \mathrm{~L} 2, \mathrm{~L} 3, \mathrm{~N} 1, \mathrm{~N} 3$

4

L1

$\mathrm{N} 2$

G2, L3 2

15

G2, G3, L2, L3, N2, N3 15

$\mathrm{N} 2$

G1, G3, L3, N3 11

L1, N1 5

G1, L1 -

N3 1

145

G1, G2, G3, L1, L2, L3, N1, N2, N3 126

G1, G2, G3, L1, L3, N1, N2, N3 19

L1, N2 3

G2, G3, L1, L2, L3, N2 31

G1, G2, G3, L1, L2, L3, N1, N2, N3 110

G1, G2, G3, L1, L2, N1, N2 52

N2 1

G3, L1 2

G1, G2, G3, L2, L3, N2, N3 18

L1 1

$\mathrm{L} 1, \mathrm{~N} 2 \quad 10$

G2, G3, L3, N1, N2, N3 15

G1, G2, L1, N1 65

G1, L3 9

G1, G2 6

G1, L1 2

G2, L2, N1, N2 9

G2, G3, L2, N2 19

G1, G2, L1, L2, N1, N2 27

G2, G3, L1, L2, L3, N2, N3 28

L1, L2 7

G2, L2, N2 10

G2 1

N1 1

L2 1

83

G2 2

G1 3

$\mathrm{N} 1 \quad 1$

G3 1

G1 1

L2 1 
Family and species

Mansuphantes mansuetus (Thorell, 1875)

Megalepthyphantes nebulosus (Sundevall, 1830) *

Microlinyphia impigra (O. P.-Cambridge, 1871) *

Neriene clathrata (Sundevall, 1830)

Neriene furtiva (O. P.-Cambridge, 1871)

Sintula spiniger (Balogh, 1935)*

Stemonyphantes lineatus (Linnaeus, 1758)

Tapinopa longidens (Wider, 1834)

Tenuiphantes cristatus (Menge, 1866)

Tenuiphantes tenuis (Blackwall, 1852)

Trichoncus auritus (L. Koch, 1869) *

Trichoncus hackmani Millidge, 1955

Walckenaeria furcillata (Menge, 1869)

Walckenaeria mitrata (Menge, 1868)

1 unidentified species

\section{Liocranidae}

Agroeca brunnea (Blackwall, 1833)

Agroeca cuprea Menge, 1873

Agroeca lusatica (L. Koch, 1875) *

Liocranum rupicola (Walckenaer, 1830)

Liocranum rutilans (Thorell, 1875)

Lycosidae

Alopecosa accentuata (Latreille, 1817) *

Alopecosa cuneata (Clerck, 1757)

Alopecosa mariae (Dahl, 1908)

Alopecosa pulverulenta (Clerck, 1757)

Alopecosa sulzeri (Pavesi, 1873)

Alopecosa trabalis (Clerck, 1757)

Arctosa figurata (Simon, 1876)

Aulonia albimana (Walckenaer, 1805)

Hogna radiata (Latreille, 1817)

Hygrolycosa rubrofasciata (Ohlert, 1865) *

Pardosa bifasciata (C. L. Koch, 1834)

Pardosa lugubris (Walckenaer, 1802)

Pardosa proxima (C. L. Koch, 1847) *

Pardosa riparia (C. L. Koch, 1833)

Trochosa ruricola (De Geer, 1778)

Trochosa terricola Thorell, 1856

Trochosa sp.

Mimetidae

Ero furcata (Villers, 1789)

Miturgidae

Cheiracanthium elegans Thorell, 1875

Cheiracanthium punctorium (Villers, 1789)

Nemesiidae

Nemesia pannonica Herman, 1879

Oxyopidae

Oxyopes lineatus Latreille, 1806

\section{Philodromidae}

Thanatus arenarius L. Koch, 1872

Thanatus atratus Simon, 1875 *

Thanatus formicinus (Clerck, 1757)

Tibellus oblongus (Walckenaer, 1802)
Site (see Table 1)

Total abundance

G3

G1

G3

L3

G1, G2, L2

G3, N2

G1, G2, L1, N1

G1, G2, G3, L3, N2

L3

G1, L1

L1, L2, N2

G3

G3

L2, N2

1

1

2

3

2

36

15

1

2

5

1

1

2

1

12

$\mathrm{L} 1, \mathrm{~N} 2$

G2, G3, N1, N2, N3 4

L1

G1

G1, N3

1

2

2

1924

G1, G2, G3, L1, L2, N1, N2 36

G1, L1, N1 46

L1 1

G1, G2, G3, L1, L2, L3, N1, N2, N3 286

G2, G3, L1, L2, N2 28

G1, G2, G3, L1, L2, N2, N3 119

L1, L2, N1

G1, G2, L2, N1, N2 14

G1, G2, G3, L1, L2, L3, N1, N2, N3 525

G2

G1, G2, L1, N1

1

209

G1, G2, G3, L1, L2, L3, N1, N2, N3 457

N1

G1, N1 2

G3, L1, L2, L3, N2 38

G1, G2, G3, L1, L2, L3, N1, N2, N3 110

47

L3

1

1

2

G2

N1

1

1

29

G1, G2, G3, L1, L2, N1, N2 29

L2

1

1

183

G1, L1, N1

9

162

G1, G2, L1, N1

11

4


Family and species

\section{Pisauridae}

Pisaura mirabilis (Clerck, 1757)

\section{Salticidae}

Euophrys herbigrada (Simon, 1871)

Euophrys sp.

Evarcha arcuata (Clerck, 1757)

Evarcha falcata (Clerck, 1757)

Evarcha laetabunda (C. L. Koch, 1846)

Heliophanus auratus C. L. Koch, 1835

Heliophanus cupreus (Walckenaer, 1802)

Marpissa muscosa (Clerck, 1757)

Marpissa nivoyi (Lucas, 1846)

Myrmarachne formicaria (De Geer, 1778)

Pellenes seriatus (Thorell, 1875)

Phlegra fasciata (Hahn, 1826)

Pseudeuophrys lanigera (Simon, 1871)

Pseudeuophrys obsoleta (Simon, 1868) *

Talavera petrensis (C. L. Koch, 1837)

Scytodidae

Scytodes thoracica (Latreille, 1802)

\section{Segestridae}

Segestria bavarica C. L. Koch, 1843

Sparassidae

Micrommata virescens (Clerck, 1757)

Tetragnathidae

Pachygnatha degeeri Sundevall, 1830

Theridiidae

Anelosimus vittatus (C. L. Koch, 1836)

Crustulina scabripes Simon, 1881

Enoplognatha thoracica (Hahn, 1833)

Euryopis flavomaculata (C. L. Koch, 1836)

Robertus lividus (Blackwall, 1836)

Steatoda phalerata (Panzer, 1801)

Thomisidae

Ozyptila atomaria (Panzer, 1801)

Ozyptila sanctuaria (O. P.-Cambridge, 1871) *

Xysticus acerbus Thorell, 1872*

Xysticus bifasciatus C. L. Koch, 1837

Xysticus cristatus (Clerck, 1757) *

Xysticus erraticus (Blackwall, 1834)

Xysticus kempeleni Thorell, 1872*

Xysticus kochi Thorell, 1872

Xysticus robustus (Hahn, 1832)

Xysticus striatipes L. Koch, 1870 *

Titanoecidae

Titanoeca veteranica L. Koch, 1872 *

Zodariidae

Zodarion hamatum Wiehle, 1964

\section{Zoridae}

Zora nemoralis (Blackwall, 1861)

Zora parallela Simon, 1878 *

Zora pardalis Simon, 1878 *

Zora silvestris Kulczyn'ski, 1897 *

Zora spinimana (Sundevall, 1833)
Site (see Table 1)

Total abundance

G1, G2, G3, L1, L2, L3, N1, N2, N3 71

$\mathrm{L} 1, \mathrm{~L} 2, \mathrm{~N} 2$

22

L2

L3, N3

$\mathrm{G} 1, \mathrm{~L} 2$

N1

G1, L1, L2, N2 7

$\mathrm{G} 2$

G2, G3

G1

G1, L2, N1, N2

$\mathrm{G} 1, \mathrm{G} 2, \mathrm{~L} 2, \mathrm{~L} 3, \mathrm{~N} 1, \mathrm{~N} 2$

N3

G1, G2, G3, L2, N3 20

$\mathrm{L} 2, \mathrm{~N} 2$

G3, L2, N2 5

G1, G2, G3, L1, L2, N1, N2, N3 29

N1

L2

L1, N3

G3

G1, G3

G3, L3

N1

22
1

3

3

7

1

2

11

9

1

20

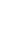

2

29

1

1

58

1

4

1

48

3

1

206

G2, N2, N3 13

G1, G2, L1, N1 18

G1, G3, L1, L2, N1, N2 16

G1

G1, L1

4

G1, G2, G3, L1, L2, L3, N1, N2

L1, L2, N1, N2 16

G1, L1, L2, N1, N2 49

G2, G3, L1, L2, N1, N2, N3 46

G1, N1 14

44

L1, N1 44

26

G1, G3, L1, L3 26

94

G3 12

G2, L1, N1 4

$\mathrm{N} 2$

G2, L1, L2, N2 38

G1, G2, G3, L1, L2, L3, N1, N2, N3 39 
Alpha diversity for each sampling site and combined per succession stage, is shown in Table 3. Beta diversity calculated for different sampling sites and different succession stages is shown in Table 4. a and Table 4. b. Table 3 also shows overall abundances within sites, localities and succession stages. Table 5 compares species richness and sampling effort (we use the number of pitfall traps operating seasonally as a proxy) in our and previous inventories of epigean spiders in the Karst, which also used pitfall traps as sample units. These data fit well to a logarithmic curve (Fig. 3: $\mathrm{F}=153.124 ; \mathrm{p}<0.001$ ).

Using Chao1, the estimated total species richness was 181+/-6, suggesting that about $25 \%$ more species were present but not collected.
Table 3: Alpha diversity (the number of species) and total abundances of adult spiders at each sampling site, locality and combined per succession stage.

Tabela 3: Alfa diverziteta (število vrst) in skupno število odraslih pajkov na vzorčnem mestu, lokaliteti ter kombinirano na vsaki sukcesijski stopnji.

\begin{tabular}{lccc} 
Site & Alpha diversity & \multicolumn{2}{c}{ Number of adults } \\
\hline G1 & 60 & 604 & \\
G2 & 55 & 362 & \\
G3 & 51 & 526 & 1492 \\
\hline L1 & 58 & 623 & \\
L2 & 51 & 284 & 1293 \\
L3 & 31 & 386 & \\
\hline N1 & 48 & 336 & \\
N2 & 53 & 401 & \\
N3 & 30 & 159 & 896 \\
\hline Succession stage & & & \\
S1 (=G1+L1+N1) & 95 & 1563 & \\
S2 (=G2+L2+N2) & 81 & 1047 & 3681 \\
S3 (=G3+L3+N3) & 64 & 1071 & \\
\hline
\end{tabular}

Table 4 (a; b): Beta diversity - a measure of the difference in species composition between sites (Table 4. a) and succession stages (Table 4. b) is shown above the diagonal, whereas the number of species occurring in both areas is shown under the diagonal.

Tabela 4 (a; b): Beta diverziteta - merilo razlike v vrstni sestavi med vzorčnimi mesti (Tabela 4. a) in sukcesijskimi stopnjami (Tabela 4. b) je prikazano nad diagonalo, medtem ko je število vrst, ki se pojavljajo $\mathrm{v}$ obeh področjih, prikazano pod diagonalo.

4. a

\begin{tabular}{lllllllllc} 
& G1 & G2 & G3 & L1 & L2 & L3 & N1 & N2 & N3 \\
\hline G1 & & 59.76 & 66.27 & 61.18 & 67.86 & 73.61 & 59.74 & 70.11 & 75.00 \\
G2 & 33 & & 54.79 & 63.86 & 56.76 & 69.70 & 60.81 & 52.05 & 62.90 \\
G3 & 28 & 33 & & 70.24 & 64.00 & 61.02 & 76.25 & 57.53 & 57.89 \\
L1 & 33 & 30 & 25 & & 58.44 & 81.33 & 62.34 & 70.93 & 76.06 \\
L2 & 27 & 32 & 27 & 32 & & 73.85 & 66.22 & 40.00 & 71.43 \\
L3 & 19 & 20 & 23 & 14 & 17 & & 80.30 & 68.75 & 58.14 \\
N1 & 31 & 29 & 19 & 29 & 25 & 13 & & 67.11 & 80.00 \\
N2 & 26 & 35 & 31 & 25 & 39 & 20 & 25 & & 72.31 \\
N3 & 18 & 23 & 24 & 17 & 18 & 18 & 13 & 18 & \\
\hline
\end{tabular}

4. $\mathrm{b}$

\begin{tabular}{cccc} 
& S1 & S2 & S3 \\
\hline S1 & & 53.33 & 66.39 \\
S2 & 56 & & 63.21 \\
S3 & 40 & 39 &
\end{tabular}




\section{DISCUSSION}

The list of 136 species recorded during our yearly inventory (Table 2) represents a remarkably rich ground spider fauna, but given the clear correlation between sampling intensity and alpha richness (Figure 3), is certainly an underestimate of the real epigean diversity of the three Karst localities. The use of nonparametric statistical richness estimation, based on observed richness and rare species (see below), suggested that the spider fauna accessible to our sampling, observed at 136 species, counted at least 181 species. Thus, the true richness was underestimated by about $25 \%$.

As expected, high abundances of cursorial ground spiders (e. g. Lycosidae, Gnaphosidae, Thomisidae, Philodromidae and Dysderidae) were recorded (Table 2). As a sample of spiders caught in pitfall traps, the list of course only accidentally includes spider species that are not epigean, notably the overgrowth and canopy faunas, which include the majority of aerial web-building spiders (families Araneidae, Tetragnathidae, Theridiidae, etc. ). A notable exception to these accidental catches of the web building fauna are wandering males of the above groups. Certainly, other sampling methods would increase the number of species collected. However, the alpha diversity of our inventory can be directly compared with Polenec's season long pitfall samplings in the Slovenian Dinaric karst from the 1960s and 1970s (Table 5). The sampling efforts in the old inventories (between 4 and 20 traps) did not come close to ours (90), and consequently, the observed species richness was much lower in the old inventories $(\alpha=32-81)$ compared to ours $(\alpha=136)$. Figure 3 shows that these values derived from the old inventories are not outliers (they fit the logarithmic curve), but simply represent sampling efforts inadequate to estimate total alpha diversity of the epigean spiders. Likewise, fitting subsets from the total effort and diversity from our inventory (Table 5, Fig. 3) underestimates real diversity: at 30 traps, the figures are still grossly underestimated, while at 60 traps the cumulative species richness (110-122) approaches comparable values as in 90 traps. However, as evident from the upward-trending curve (Fig. 3) and species richness estimation, even this final diversity at 136 is underestimated.

The presence of "rare" species (singletons, doubletons) in arthropod inventories is problematic, as they cannot be biologically real and their
Table 5: A comparison of alpha diversity $(\alpha)$ and sampling effort (number of pitfall traps operating seasonally) among inventories of epigean spiders in the Karst.

Tabela 5: Primerjava alfa diverzitete $(\alpha)$ in intenzitete vzorčenja (število pasti, ki so delovale vso sezono) med posameznimi vzorčenji površinskih pajkov Krasa.

\begin{tabular}{llll}
$\boldsymbol{\alpha}$ & Effort & Site & Author \\
\hline 32 & 12 & Nanos & Polenec 1963 \\
44 & 12 & Divača & Polenec 1965 \\
50 & 12 & Divača & Polenec 1968 \\
36 & 4 & Nanos & Polenec 1969 \\
81 & 20 & Slavnik & Polenec 1978 \\
60 & 10 & G1 & this paper \\
55 & 10 & G2 & this paper \\
51 & 10 & G3 & this paper \\
58 & 10 & L1 & this paper \\
51 & 10 & L2 & this paper \\
31 & 10 & L3 & this paper \\
48 & 10 & N1 & this paper \\
53 & 10 & N2 & this paper \\
30 & 10 & N3 & this paper \\
95 & 30 & Griže & this paper \\
88 & 30 & Lokvica & this paper \\
85 & 30 & Novelo & this paper \\
122 & 60 & Griže and Lokvica & this paper \\
121 & 60 & Griže and Novelo & this paper \\
110 & 60 & Lokvica and Novelo & this paper \\
136 & 90 & All Karst sites & this paper \\
\hline
\end{tabular}

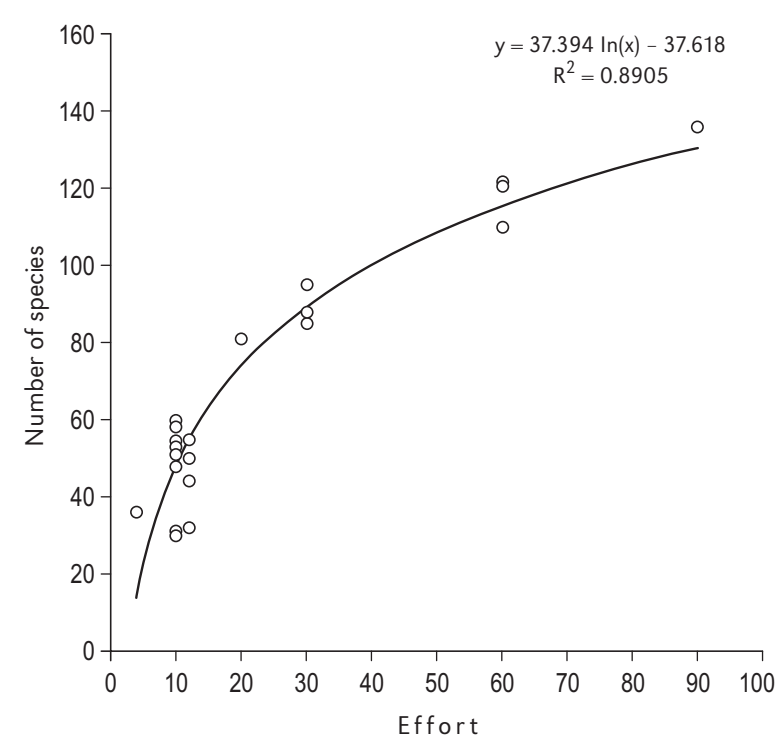

Figure 3: A comparison of sampling effort (number of pitfall traps operating seasonally) among inventories of epigean spiders in the Karst.

Slika 3: Primerjava intenzitete vzorčenja (število pasti, ki so delovale vso sezono) med posameznimi vzorčenji površinskih pajkov Krasa. 
numbers prevent accurate statistical estimates of richness (Coddington et al. 2009). Scharff et al. (2003), working on northern European forest spider fauna, explained the presence of singletons mostly as edge effects, such as accidental catches by a method (see above), or outside of the species seasonality. However, Coddington et al. (2009) tested edge effects and a number of other biological explanations against the null hypothesis of undersampling bias, and showed, that at least in the tropics, rare species are mostly due to the latter. Our 38 singletons and 16 doubletons certainly suggest that the sampling effort in our study, although much higher than in previous studies from the area, was still inadequate. A higher effort would see singleton numbers drop below doubleton numbers, tending towards inventory completion (Colwell \& Coddington 1994). However, such inventory completeness is rarely, if ever, achieved in sampling diverse taxonomic groups such as spiders (Coddington et al. 2009).

Comparing the diversity of the Karst epigean spider fauna in different succession stages reveals that the overall species richness is highest in grasslands, followed by the overgrowth and forest (Table 3). In Novelo most species were found in the overgrowth, followed by grassland and forest (Table 3). Although the overgrowth and/ or canopy layers contain more vegetation layers than grassland and therefore potentially more species and individuals (Sørensen et al. 2002, but see Coddington et al. 2009), these were not accessed by our sampling method.

The most adult spiders were caught in grassland, followed by the forest and by overgrowth (Table 3). As in alpha diversity, such trend in number of adults was also present within two out of three localities (Griže, Lokvica) but not in Novelo (Table 3).

As expected, beta diversity shows a higher similarity in species composition between adjacent succession stages (grassland-overgrowth and overgrowth-forest) within a site than between less similar succession stages (grasslandforest) (Table 4. a). For example, the differences between G1 (grassland) and G2 (overgrowth) and between G2 and G3 (forest) were less than the difference between G1 and G3, and the overall pattern was the same (Table 4. b). Perhaps unexpectedly, the similarities between two adjacent succession stages within a locality (e. g. L1 and L2) were sometimes, but not always (e. g. N1 and N2), greater than those between the same suc- cession stages of different localities (Table 4. a). However, as expected, grassland faunas always differed more from the forest faunas than from other grassland faunas (Table 4. b).

The spider species richness seasonal patterns show maximum values in the spring, much less in the summer and autumn, and minimal abundances during the winter (Fig. 2. a). Similarly, seasonal abundances are highest in late spring and early summer, but are much lower in the autumn. Such fluctuations may be explained by the gradual emergence of overwintering spiders. Peak spring abundances (Fig. 2. a and 2. b) are partly due to reproduction by spiders which had overwintered as adults or penultimate instars (Abraham, 1983).

A surprisingly large proportion (20.6\%) of the total number of species have previously not been recorded in Slovenia (Table 2). Without exception, these species represent widespread taxa occupying areas at least of the range of Eastern Europe to the whole Holarctic (Platnick 2008). These newly recorded species should thus be more common in Slovenia and neighbouring regions than the literature data might suggest. This reiterates the claims of Kuntner \& Šereg (2002) that the spider fauna of Slovenia, including this contribution currently standing at 615 species, continues to be inadequately known.

\section{CONCLUSIONS}

Our inventory, which was the largest epigean sampling in Slovenia in terms of species richness (136), sampling effort (90 yearly pitfall traps) and abundances (3681 adult spiders in total), added 28 species as new to Slovenian fauna, and provided preliminary evidence for higher species richness and abundances of epigean spiders in Karst grasslands in comparison with the two succession stages, overgrowth and forest. We conclude that the sampling effort needed for a meaningful estimation of epigean spider diversity (estimated at 181 species) was barely sufficient in our study, but completely inadequate in previous samplings.

\section{ACKNOWLEDGEMENTS}

We thank Olga Kardoš and Božidar Drovenik for their field assistance, Jonathan A. Coddington, Ingi Agnarsson, Ivan Kos, Tatjana Čelik and Simona Kralj-Fišer for comments, and Krištof Oštir 
for making available the base map for Fig. 1. This work was supported by the Slovenian Research Agency (ARRS grant L1-6587-0618).

\section{REFERENCES}

Abraham, B. J. 1983: Spatial and temporal patterns in a sagebrush steppe spider community (Arachnida : Araneae). Journal of Arachnology 11: 31-50.

Cardoso, P., Gaspar, C., Pereira, L. C., Silva, I., Henriques, S. S., da Silva, R. R. \& Sousa, P. 2008: Assessing spider species richness and composition in Mediterranean cork oak forests. Acta Oecologica 33: 114-127. (DOI: 101016/j.actao.2007.10.003)

Chao, A. 1984: Non-parametric estimation of the number of classes in a population. Scandinavian Journal of Statistics 11: 265-270.

Coddington, J. A., Young, L. H. \& Coyle, F. A. 1996: Estimating spider species richness in a southern Appalachian cove hardwood forest. Journal of Arachnology 24: 111-128.

Coddington, J. A., Agnarsson, I., Miller, J., Kuntner, M. \& Hormiga, G. 2009. Undersampling bias: the null hypothesis for singleton species in tropical arthropod surveys. Journal of Animal Ecology 78. (DOI: 10.1111/j.1365-2656. 2009.01525.x)

Colwell, R. K. \& Coddington, J. A. 1994: Estimating terrestrial biodiversity through extrapolation. Philosophical Transactions of the Royal Society of London B 345: 101-118.

Culver, D. C., Deharveng, L., Bedos, A., Lewis, J. J., Madden, M., Reddell, J. R., Sket, B., Trontelj, P. \& White, D. 2006: The mid-latitude biodiversity ridge in terrestrial cave fauna. Ecography 29: 120-128 (DOI:10.1111/j.2006.09067590.04366.x).

Kokalj, Ž. \& Oštir, K. 2007: Land cover mapping using landsat satellite image classification in the classical Karst-Kras region. Acta Carsologica 36: 433-440.

Kuntner, M. 1997a: Prispevek k poznavanju favne pajkov jugozahodne Slovenije in ugotavljanje vrstnega bogastva pajkov gozda na Brkinih (Arachnida: Araneae). In: M. Bedjanič, Raziskovalni tabor študentov biologije Podgrad '96. Ljubljana: Zveza organizacij za tehnično kulturo: 11-32.

Kuntner, M. 1997b: A contribution to the knowledge of the Slovenian spider fauna: eleven species new for Slovenia and some other interesting findings (Arachnida, Araneae). In: M. Żabka, Proc. $16^{\text {th }}$ European Colloquium of Arachnology. Siedlce, Poland: 165-172.

Kuntner, M. 1997c: Jumping spiders new to Slovenia (Arachnida: Araneae: Salticidae). Acta Entomologica Slovenica 5: 117-122.

Kuntner, M. 1999: Prispevek k poznavanju favnistike in ekologije pajkov severovzhodne Slovenije (Arachnida: Araneae). Natura Sloveniae 1: 29-44.

Kuntner, M. \& Baxter, I. H. 1997: A Preliminary investigation of spider species richness in an eastern Slovenian broadleaf forest. In: M. Żabka, Proc. $16^{\text {th }}$ European Colloquium of Arachnology. Siedlce, Poland, 173-182 pp.

Kuntner, M. \& Kostanjšek, R. 2000: Prispevek k poznavanju favne pajkov zahodne Slovenije (Arachnida: Araneae). Natura Sloveniae 2: 13-28.

Kuntner, M. \& Šereg, I. 2002: Additions to the spider fauna of Slovenia, with a comparison of spider species richness among European countries. Bulletin of the British Arachnological Society 12: 185-195.

Moreno, C. E. \& Halffter, G. 2001: Spatial and temporal analysis of $\alpha, \beta$ and $\delta$ diversities of bats in a fragmented landscape. Biodiversity and Conservation 10: 367-382.

Platnick N. I. 2008. The World Spider Catalog, Version 8. 5. The American Museum of Natural History. [http://research. amnh. org/entomology/spiders/catalog/]

Polenec, A. 1963: Terestrična arahnidska favna v gozdovih pod Nanosom. Biološki vestnik 11: 79-88.

Polenec, A. 1965: Raziskovanje arahnidske favne na Krasu. Nasad črnega bora (Pinus nigra Arn.) v združbi Seslerio autumnalis-Ostryetum pri Divači. Biološki vestnik 13: 77-85.

Polenec, A. 1968: Raziskovanje terestrične arahnidske favne na Krasu. Pašniško področje v rastlinski združbi Seslerio autumnalis-Ostryetum pri Divači. Biološki vestnik 16: 77-85.

Polenec, A. 1969: Favnistično ekološka raziskovanja arahnidske favne na Nanosu. Biološki vestnik 17: 113-123.

Polenec, A. 1971: Arahnidska favna s pobočij Javornikov in Slivnice. Mladinski raziskovalni tabori 1970.

Polenec, A. 1973: Pajki z območja Notranjskega Snežnika (1796 m). Mednarodni mladinski raziskovalni tabori 1971-1972. 
Polenec, A. 1978: Zusammensetzung und Besonderheiten der epigäischen Spinnenfauna des Seslerio-Ostryetum am Berge Slavnik (1028 m) (Nord-Istrien, Jugoslawien). Symposia of the Zoological Society of London 42: 367-377.

Polenec, A. 1992: Rdeči seznam ogroženih pajkov (Aranea) Slovenije. Varstvo narave. 17: 173-176.

Scharff, N., Coddington, J. A., Griswold, C. E., Hormiga, G. \& de Place Björn, P. 2003: When to Quit? Estimating spider species richness in a northern European deciduous forest. Journal of Arachnology 31: 246-273.

Sørensen, L. L., Coddington, J. A. \& Scharff, N. 2002: Inventorying and estimating sub-canopy spider diversity using semi-quantitative sampling methods in an Afromontane forest. Environmental Entomology 31: 319-330.
Uradni list Republike Slovenije 2002: Pravilnik o uvrstitvi ogroženih rastlinskih in živalskih vrst v rdeči seznam, MP82/02: 8893-8975. Version 2002. Available from: http://www. uradni-list. si/1/ulonline. jsp?urlid=200282\&dhid $=44228$.

Whittaker, R. H. 1977: Evolution of species diversity in land communities. Evolutionary Biology 10: $1-67$.

Zagmajster, M., Culver, D. C. \& Sket, B. 2008: Species richness patterns of obligate subterranean beetles (Insecta: Coleoptera) in a global biodiversity hotspot effect of scale and sampling intensity. Diversity and Distributions 14: 95-105. (DOI: 10.1111/j.1472-4642. 2007.00423.x) 